\title{
Sequential Treatment of Multiple Actinic Keratoses with Solaraze and Actikerall
}

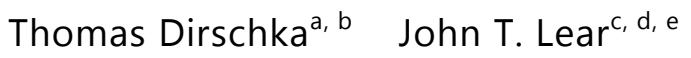 \\ ${ }^{a}$ Private Dermatological Practice Centre, Wuppertal, and ${ }^{b}$ Faculty of Health, \\ Witten/Herdecke University, Witten, Germany; ${ }^{\mathrm{C}}$ Dermatology Centre, University of \\ Manchester, Manchester Academic Health Science Centre, ${ }^{d}$ Salford Royal NHS Foundation \\ Trust and ${ }^{\mathrm{e}}$ Manchester Royal Infirmary, Manchester, UK
}

\section{Key Words}

5-Fluorouracil · Actikerall · Actinic keratosis · Diclofenac · Quality of life · Salicylic acid . Sequential treatment $\cdot$ Solaraze

\begin{abstract}
Interest is increasing in the use of sequential or combined therapeutic modalities for spot or area treatment of actinic keratoses (AKs) to achieve complete sustained remission. For multiple lesions in a contained area, topical treatment offers less discomfort, better cosmesis and greater patient convenience than destructive/ablative techniques. Twelve patients with multiple grade I and II AK lesions of the scalp (cases 1-10) or the dorsum of the hand (cases 11 and 12), most with a history of recurrence, were treated with Solaraze gel (3\% diclofenac sodium in $2.5 \%$ hyaluronic acid) twice daily for 12 weeks, followed by a 2-week treatment-free interval, then Actikerall cutaneous solution (5-fluorouracil $5 \mathrm{mg} / \mathrm{g}$ and salicylic acid $100 \mathrm{mg} /$ g) once daily for up to 6 weeks as required. Sequential treatment provided complete (clinical and histological) clearance in $8 / 10$ male patients. Two patients with numerous lesions had partial clearance (significant improvement) and the remaining few lesions were treated with erbium laser. Both female patients achieved complete clinical clearance with sequential treatment. Solaraze/Actikerall were well tolerated. A case of contact dermatitis with Solaraze resolved after discontinuation and the patient progressed to treatment with Actikerall. Local application site reactions resolved upon treatment completion. Topical lesion-directed sequential treatment with Solaraze/Actikerall is a rational approach to treat patients with multiple AKs. Sequential treatment produces excellent clearance rates which are accompanied by relevant improvement in patients' quality of life.


Dirschka and Lear: Sequential Treatment of Multiple Actinic Keratoses with Solaraze and Actikerall

\section{Introduction}

Actinic keratoses (AKs) are among the most frequent diagnoses in dermatological practice [1]. The exponential increase in the incidence of AKs and their potential to evolve to squamous cell carcinoma have made the condition an increasingly important strategic health issue [2]. Early and effective treatment is essential to minimise both the individual and societal burden.

Therapeutic options for AKs include cryotherapy, curettage with or without electrosurgery, laser therapy, photodynamic therapy, chemical peeling and topical treatments such as imiquimod, diclofenac and 5-fluorouracil (5-FU) [3-5]. Selection of the most appropriate treatment modality depends on individual patient characteristics and clinical presentation. AKs can present as a single well-defined lesion, as multiple disseminated lesions or as field cancerisation whereby lesions of various grades from sub-clinical to invasive squamous cell carcinoma co-exist in the same vicinity or 'field' [3]. Single lesions, particularly if hyperkeratotic, are often treated with cryotherapy, curettage or laser therapy [3]. However, targeting only a single lesion can leave behind neighbouring mutant keratinocytes with the potential to evolve to AKs [6]. Moreover, in the case of multiple lesions concentrated in a small area, topical therapy provides several potential advantages over destructive techniques, such as less discomfort, better cosmetic outcomes and increased patient convenience [7].

Sequential or combined therapeutic modalities for spot or area treatment of AKs are receiving increasing interest as a method to achieve complete sustained remission [2]. In this report, we describe clinical cases where patients with multiple AKs were treated in a sequential manner with Solaraze gel (3\% diclofenac sodium in $2.5 \%$ hyaluronic acid) and Actikerall cutaneous solution (5-FU $5 \mathrm{mg} / \mathrm{g}$ and salicylic acid $100 \mathrm{mg} / \mathrm{g}$ ) according to a predefined treatment plan.

\section{Case Presentation}

A total of 12 patients were treated, 10 male patients with AKs of the scalp (cases 1-10) and 2 female patients with multiple AKs on the dorsum of the right hand (cases 11 and 12). Patients' demographic and clinical characteristics, treatment details and treatment outcomes are summarised in table 1.

The patients ranged in age from 40 to 64 years and all but 3 had a prior history of AKs. Other relevant histories were 2 patients with previous or co-existing basal cell carcinoma and 1 patient each with co-existing keratoacanthoma, nonmelanoma skin cancer or Bowen's disease. Previous treatments included cryotherapy, photodynamic therapy, curettage, Solaraze, erbium $/ \mathrm{CO}_{2}$ laser and imiquimod $5 \%$ cream. All patients had multiple grade I and II AK lesions by Olsen definition [8] and, in male patients only, a histological grading of AK I to AK III for one representative lesion. In 7 of the 10 male patients, AK had been having a 'moderate' to 'very large' effect on their quality of life (pre-treatment Dermatology Life Quality Index [DLQI] scores $>6$ ).

Solaraze was applied to lesion sites on the bald scalp or dorsal surface of the right hand twice daily for 12 weeks, followed by a treatment-free interval of 2 weeks, then once-daily application of Actikerall to any remaining lesions for up to 6 weeks as required.

Complete (clinical and histological) clearance was achieved in 8/10 male patients, in 2 of the patients with Solaraze alone and in 6 patients with sequential treatment. In the latter group, most lesions responded to Solaraze and the remaining lesions were cleared with Actikerall. Cases 4 and 8 presented high lesion numbers (26 and 19, respectively) and 
Dirschka and Lear: Sequential Treatment of Multiple Actinic Keratoses with Solaraze and Actikerall

histories of multiple recurrences. Both patients improved significantly with sequential treatment; the few remaining lesions in each patient underwent erbium laser ablation.

Complete clinical clearance was achieved in both female patients. In case 11, 6 of 8 lesions remained after 12 weeks' treatment with Solaraze but were subsequently cleared during treatment with Actikerall. In case 2, complete clinical clearance was achieved with Solaraze, but the patient was instructed to continue with Actikerall. At follow-up 20 weeks after treatment initiation, all 4 original lesions were cleared; however, a new grade I lesion was observed.

Solaraze and Actikerall were generally well tolerated. Adverse events associated with treatment were typical of those reported during clinical development $[9,10]$ and resolved upon discontinuation or completion of treatment. In male patients, one case each of moderate erythema and contact dermatitis occurred with Solaraze. The contact dermatitis resolved after Solaraze was discontinued and the patient proceeded to treatment with Actikerall. Both female patients experienced mild erythema and scaling but were able to continue with treatment. The main adverse event reported with Actikerall was application site irritation, which resolved after completion of treatment in all cases.

The efficacy of Solaraze/Actikerall sequential treatment was reflected in the DLQI scores (available for male patients only). The mean DLQI score decreased from 8.9 before treatment to 3.7 after treatment; in 3 cases, the post-treatment DLQI score was 0.

Both female patients expressed satisfaction with Solaraze/Actikerall sequential treatment; case 11 considered it to be the best therapy she had received thus far, and case 12 reported marked improvement in her quality of life.

\section{Discussion}

Herein, 12 patients are described with multiple and mainly recurrent AKs of the scalp or dorsal surface of the hand treated sequentially with Solaraze/Actikerall according to a predefined treatment protocol. Topical lesion-directed sequential treatment was highly effective, providing complete clearance of grade I and II AK lesions in 10/12 patients and improving quality of life. Two male patients with numerous lesions (26 and 19) and histories of multiple recurrences achieved significant improvement with sequential therapy; 3 remaining lesions in case 4 and 4 remaining lesions in case 8 underwent subsequent ablation by erbium laser. Solaraze/Actikerall sequential treatment was well tolerated. Associated adverse events were in line with those reported during clinical development of the products $[9,10]$ and resolved upon discontinuation or completion of treatment.

In AK, diclofenac is thought to act by blocking cyclooxygenase- 2 in the arachidonic acid cascade, thereby reducing angiogenesis and cellular proliferation. Topical diclofenac has also been shown to induce apoptosis. The therapeutic effect of Solaraze may therefore relate to diclofenac simultaneously 'starving' dysplastic keratinocytes and promoting programmed cell death, resulting in lesion clearance with minimal inflammation [11].

The cytostatic effect of 5-FU occurs through pathways which adversely affect the synthesis and functioning of RNA and DNA [12]. Topical 5-FU may also stimulate p53-mediated apoptosis of rapidly proliferating cells found in dermatological lesions such as AKs [12].

The mechanism of action of topical salicylic acid as a keratolytic and corneolytic agent in AKs is thought to relate to its interference with corneocyte adhesion, its solubilising effect on intercellular cement, and through the loosening and detachment of corneocytes. As a keratolytic agent, salicylic acid may remove intercellular lipids linked covalently to the cornified envelope surrounding cornified cells [9]. 
Dirschka and Lear: Sequential Treatment of Multiple Actinic Keratoses with Solaraze and Actikerall

Sequential treatment with Solaraze/Actikerall thus represents a rational two-step approach to the treatment of AKs. The high complete (clinical and histological) clearance rate achieved with initial use of Solaraze can limit the length of patients' exposure to 5-FU/ salicylic acid, thereby reducing the risk and intensity of application site reactions. Lesions still present after Solaraze can be 'tidied up' with Actikerall, and any remaining lesions can be treated with laser ablation as necessary.

In conclusion, Solaraze/Actikerall sequential therapy can be recommended as an alternative to destructive or ablative treatment modalities in patients with multiple concentrated AKs, including patients with a history of lesion recurrence.

\section{Disclosure Statement}

Writing assistance was provided by Content Ed Net, with funding from Laboratorios Almirall, SA (Barcelona, Spain).

\section{References}

1 Ceilley RI, Jorizzo JL: Current issues in the management of actinic keratosis. J Am Acad Dermatol 2013;68 (suppl 1):S28-S38.

-2 Nashan D, Meiss F, Müller M: Therapeutic strategies for actinic keratoses - a systematic review. Eur J Dermatol 2013;23:14-32.

-3 Stockfleth E, Ferrandiz C, Grob JJ, Leigh I, Pehamberger H, Kerl H; European Skin Academy: Development of a treatment algorithm for actinic keratoses: a European Consensus. Eur J Dermatol 2008;18:651-659.

4 Silapunt S, Goldberg LH, Alam M: Topical and light-based treatments for actinic keratoses. Semin Cutan Surg 2003;22:162-170.

5 McIntyre WJ, Downs MR, Bedwell SA: Treatment options for actinic keratoses. Am Fam Physician 2007;76: 667-671.

6 Rigel DS, Stein Gold LF: The importance of early diagnosis and treatment of actinic keratosis. J Am Acad Dermatol 2013;68(suppl 1):S20-S27.

7 Berman B, Amini S: Pharmacotherapy of actinic keratosis: an update. Expert Opin Pharmacother 2012;13: 1847-1871.

-8 Olsen EA, Abernethy ML, Kulp-Shorten C, Callen JP, Glazer SD, Huntley A, McCray M, Monroe AB, Tschen E, Wolf JE Jr: A double-blind, vehicle-controlled study evaluating masoprocol cream in the treatment of actinic keratoses on the head and neck. J Am Acad Dermatol 1991;24:738-743.

9 Solaraze summary of product characteristics. www.biocsl.com.au/docs/8/377/Solaraze $\% 20 \mathrm{PI} \% 20$ \%20approved\%20Dec2008,0.pdf (last accessed January 2014).

10 Actikerall summary of product characteristics. www.medicines.org.uk/emc/medicine/24614/SPC/ Actikerall+5mg+g+\%2B+100mg+g+Cutaneous+Solution/ (last accessed January 2014).

11 Nelson CG: Diclofenac gel in the treatment of actinic keratoses. Ther Clin Risk Manag 2011;7:207-211.

12 Ceilley RI: Mechanisms of action of topical 5-fluorouracil: review and implications for the treatment of dermatological disorders. J Dermatolog Treat 2012;23:83-89. 
Dirschka and Lear: Sequential Treatment of Multiple Actinic Keratoses with Solaraze and Actikerall

Table 1. Clinical characteristics, treatment details and treatment outcomes of patients with multiple AKs of the scalp (cases 1-10) and dorsum of the hand (cases 11 and 12)

\begin{tabular}{|c|c|c|c|c|c|c|c|c|}
\hline $\begin{array}{l}\text { Pa- } \\
\text { tient } \\
\text { No. }\end{array}$ & $\begin{array}{l}\text { Age/history/ } \\
\text { DLQI before } \\
\text { treatment }\end{array}$ & $\begin{array}{l}\text { Photo- } \\
\text { type }\end{array}$ & $\begin{array}{l}\text { No. of lesions, } \\
\text { Olsen grade/ } \\
\text { histological grade }\end{array}$ & $\begin{array}{l}\text { Previous } \\
\text { treatment }\end{array}$ & $\begin{array}{l}\text { Dosage of } \\
\text { Solaraze/ } \\
\text { Actikerall }\end{array}$ & Outcome & Adverse events & $\begin{array}{l}\text { Physician Global } \\
\text { Assessment/DLQI after } \\
\text { treatment }\end{array}$ \\
\hline 1 & $40 /$ neg/4 & I & $\begin{array}{l}6 \times 0 \text { I; } 1 \times 0 \text { II; } \\
1 \times \text { hist: AK II }\end{array}$ & none & $\mathrm{S} 120 \mathrm{~g}$ & $\mathrm{CC}$ (clin + hist) & none & $\begin{array}{l}\text { clearing, high } \\
\text { satisfaction/1 }\end{array}$ \\
\hline 2 & $\begin{array}{l}\text { 58/AK, } \\
\mathrm{BCC} / 10\end{array}$ & II & $\begin{array}{l}5 \times 0 \text { I; } 7 \times 0 \mathrm{II} \\
1 \times \text { hist: AK II }\end{array}$ & $\begin{array}{l}\text { Cryo } 3 \text { yrs } \\
\text { ago }\end{array}$ & $\begin{array}{l}\text { S } 240 \mathrm{~g} \\
\text { A } 10 \mathrm{ml}\end{array}$ & $\begin{array}{l}\text { PC after } 12 \text { wks; } 3 \text { lesions treated } \\
\text { with A for } 4 \text { wks; CC (clin + hist) }\end{array}$ & $\begin{array}{l}\text { skin irritation after } \\
4 \text { wks with A; } \\
\text { outcome: resolved }\end{array}$ & $\begin{array}{l}\text { clearing, satisfaction, } \\
\text { slight erythema } / 7\end{array}$ \\
\hline 3 & $52 / \mathrm{AK} / 5$ & II & $\begin{array}{l}6 \times 0 \text { I; } 2 \times 0 \mathrm{II} \\
1 \times \text { hist: pig- } \\
\text { mented AK II }\end{array}$ & $\begin{array}{l}\text { PDT } 2 \text { yrs } \\
\text { ago } \rightarrow \\
\text { painful }\end{array}$ & $\begin{array}{l}\text { S } 180 \mathrm{~g} \\
\text { A } 5 \mathrm{ml}\end{array}$ & $\begin{array}{l}\text { PC after } 12 \text { wks; } 1 \times 0 \text { II lesion } \\
\text { remaining; lesion treated with A for } \\
3 \text { wks; CC (clin + hist) }\end{array}$ & none & $\begin{array}{l}\text { clearing, high } \\
\text { satisfaction } / 0\end{array}$ \\
\hline 4 & $52 / \mathrm{AK} / 12$ & I & $\begin{array}{l}15 \times 0 \mathrm{I} ; 11 \times 0 \mathrm{II} \\
1 \times \text { hist: AK III }\end{array}$ & $\begin{array}{l}\text { curettage } \\
>10 \text { times, } \\
\text { last } \\
\text { treatment } \\
1 \text { yr ago }\end{array}$ & $\begin{array}{l}\mathrm{S} 280 \mathrm{~g} \\
\text { A } 20 \mathrm{ml}\end{array}$ & $\begin{array}{l}\mathrm{PC} \text { after } 12 \text { wks; } 6 \times 0 \text { I and } 6 \times 0 \text { II } \\
\text { lesions remaining; after treatment } \\
\text { with } \mathrm{A}, 1 \times 0 \mathrm{I} \text { and } 2 \times 0 \text { II lesions } \\
\text { remaining; } \mathrm{PC}(\mathrm{clin}+\text { hist: AK II) }\end{array}$ & $\begin{array}{l}\text { irritation at } \\
\text { application site of A; } \\
\text { outcome: resolved }\end{array}$ & $\begin{array}{l}\text { profound improvement; } \\
2 \text { remaining lesions were } \\
\text { treated with erbium } \\
\text { laser } / 4\end{array}$ \\
\hline 5 & $49 /$ neg/3 & I & $\begin{array}{l}4 \times 0 \text { I; } 3 \times 0 \text { II; } \\
1 \times \text { hist: AK II }\end{array}$ & none & $\begin{array}{l}\mathrm{S} 80 \mathrm{~g} \\
\text { A } 5 \mathrm{ml}\end{array}$ & $\begin{array}{l}\text { PC after } 12 \text { wks; } 1 \times 0 \text { II lesion } \\
\text { remaining; lesion treated with A for } \\
2 \text { wks; CC (clin + hist) }\end{array}$ & $\begin{array}{l}\text { slight irritation at } \\
\text { application site of A; } \\
\text { outcome: resolved }\end{array}$ & high satisfaction/0 \\
\hline 6 & $42 /$ neg/8 & II & $\begin{array}{l}8 \times 0 \text { I; } 2 \times 0 \text { II; } \\
1 \times \text { hist: AK I }\end{array}$ & none & $\begin{array}{l}\text { S } 120 \mathrm{~g} \\
\text { A } 10 \mathrm{ml}\end{array}$ & $\begin{array}{l}\text { PC after } 12 \text { wks; } 2 \times 0 \text { II lesions } \\
\text { remaining; lesion treated with A for } \\
3 \text { wks; CC (clin + hist) }\end{array}$ & $\begin{array}{l}\text { moderate erythema } \\
\text { of scalp by end of S; } \\
\text { slight irritation at } \\
\text { application site of A; } \\
\text { outcome: resolved }\end{array}$ & $\begin{array}{l}\text { good result but slightly } \\
\text { disappointed because of } \\
\text { erythema/4 }\end{array}$ \\
\hline 7 & $\begin{array}{l}\text { 55/BCC } 1 \mathrm{yr} \\
\text { ago/8 }\end{array}$ & II & $\begin{array}{l}7 \times 0 \text { I; } 1 \times 0 \text { II; } \\
1 \times \text { hist: AK I }\end{array}$ & $\begin{array}{l}\text { S } 3 \text { yrs ago } \\
\text { for } 12 \text { wks }\end{array}$ & $\mathrm{S} 120 \mathrm{~g}$ & CC after 8 wks & none & very satisfied/0 \\
\hline 8 & $\begin{array}{l}\text { 57/AKs on } \\
\text { scalp and } \\
\text { face; kerato- } \\
\text { acanthoma } \\
\text { on scalp/17 }\end{array}$ & I & $\begin{array}{l}14 \times \text { O I; } 5 \times 0 \mathrm{II} \\
1 \times \text { hist: AK II }\end{array}$ & $\begin{array}{l}\text { Cryo } 5 \text { yrs } \\
\text { ago; PDT } \\
2 \text { yrs ago }\end{array}$ & $\begin{array}{l}\text { S } 260 \mathrm{~g} ; \\
\text { A } 25 \mathrm{ml}\end{array}$ & $\begin{array}{l}\text { PC after } 12 \text { wks; } 10 \text { lesions } \\
\text { remaining; PC after } 20 \text { wks; } \\
4 \text { lesions remaining; hist: AK II; } \\
\text { ablation by erbium laser }\end{array}$ & $\begin{array}{l}\text { moderate to severe } \\
\text { irritation at wk } 20 ; \\
\text { headache in last wk } \\
\text { of treatment }\end{array}$ & $\begin{array}{l}\text { satisfied given the } \\
\text { severity of the case } / 11\end{array}$ \\
\hline 9 & $\begin{array}{l}\text { 53/AKs at } \\
\text { front/12 }\end{array}$ & II & $\begin{array}{l}3 \times 0 \mathrm{I} ; 4 \times 0 \mathrm{II} \\
1 \times \text { hist: AK II }\end{array}$ & $\begin{array}{l}\text { erbium } \\
\text { laser } 2 \text { yrs } \\
\text { ago }\end{array}$ & $\begin{array}{l}\text { S } 100 \mathrm{~g} \\
\text { A } 5 \mathrm{ml}\end{array}$ & $\begin{array}{l}\text { PC after } 12 \text { wks; } 2 \times 0 \text { II lesions } \\
\text { remaining; lesion treated with A for } \\
3 \text { wks; CC (clin + hist) }\end{array}$ & none & very satisfied/4 \\
\hline 10 & $\begin{array}{l}\text { 49/AKs on } \\
\text { scalp/10 }\end{array}$ & I & $\begin{array}{l}9 \times 0 \text { I; } 3 \times 0 \text { II; } \\
1 \times \text { hist: AK II }\end{array}$ & $\begin{array}{l}\mathrm{CO}_{2} \text { laser } \\
3 \text { yrs ago }\end{array}$ & $\begin{array}{l}\mathrm{S} 50 \mathrm{~g} \\
\text { A } 25 \mathrm{ml}\end{array}$ & $\begin{array}{l}\text { PC after } 3 \text { wks of S; discontinuation } \\
\text { due to contact dermatitis; after } \\
2 \text { wks started treatment with A; } \\
\text { CC (clin + hist) }\end{array}$ & $\begin{array}{l}\text { contact dermatitis } \\
\text { after } 3 \text { wks of S; } \\
\text { resolved } 2 \text { wks after } \\
\text { discontinuation }\end{array}$ & $\begin{array}{l}\text { satisfied despite } \\
\text { occurrence of contact } \\
\text { dermatitis } 6\end{array}$ \\
\hline 11 & $\begin{array}{l}\text { 64/AK, } \\
\text { NMSC }\end{array}$ & I & $5 \times 0 \mathrm{I} ; 3 \times 0 \mathrm{II}$ & Imiq & $\begin{array}{l}\text { S } 120 \mathrm{~g} \\
\text { A } 25 \mathrm{ml}\end{array}$ & $\begin{array}{l}\text { PC after } 12 \text { wks of S; } 6 \text { lesions } \\
\text { treated with A for } 6 \text { wks; CC (clin) }\end{array}$ & $\begin{array}{l}\text { mild erythema and } \\
\text { scaling; outcome: } \\
\text { resolved }\end{array}$ & not reported \\
\hline 12 & $\begin{array}{l}\text { 62/AK, } \\
\text { Bowen's } \\
\text { disease }\end{array}$ & I & $4 \times 0 \mathrm{I}$ & Imiq & $\begin{array}{l}\mathrm{S} 60 \mathrm{~g} \\
\text { A } 10 \mathrm{ml}\end{array}$ & $\begin{array}{l}\text { CC after } 12 \text { wks of S; despite } \\
\text { clearance, lesions treated with A for } \\
6 \text { wks; CC (clin); new } 1 \times 0 \text { I lesion } \\
\text { observed }\end{array}$ & $\begin{array}{l}\text { mild erythema and } \\
\text { scaling; outcome: } \\
\text { resolved }\end{array}$ & not reported \\
\hline
\end{tabular}

$\mathrm{A}=$ Actikerall; $\mathrm{BCC}=$ basal cell carcinoma; $\mathrm{CC}=$ complete clearance; clin = clinical; Cryo = cryotherapy; hist = histological; Imiq = imiquimod $5 \%$ cream; neg = negative; NMSC = nonmelanoma skin cancer; $\mathrm{O}=$ Olsen grade; $\mathrm{PC}=$ partial clearance; $\mathrm{PDT}=$ photodynamic therapy; $\mathrm{S}=$ Solaraze; $\mathrm{wks}=$ weeks; $\mathrm{yrs}=$ years 